\title{
Anxiety and Depression Symptoms of Patients in Fangcang Shelter Hospital During the COVID-19 Outbreak in China: a Web-Based Cross-Sectional Study
}

\section{Ling-Ling Dai}

Zhengzhou University First Affiliated Hospital

\section{Xi Wang}

Zhengzhou University First Affiliated Hospital

Tian-Chi Jiang

Zhengzhou University First Affiliated Hospital

\section{Peng-Fei Li}

Zhengzhou University First Affiliated Hospital

\section{Yu Wang}

Zhengzhou University First Affiliated Hospital

\section{Shu-Jun Wu}

Zhengzhou University First Affiliated Hospital

\section{Liu-Qun Jia}

Zhengzhou University First Affiliated Hospital

\section{Meng Liu}

Zhengzhou University First Affiliated Hospital

\section{Lin An}

Zhengzhou University First Affiliated Hospital

Zhe Cheng ( $\nabla$ chengzhezzu@outlook.com )

Zhengzhou University First Affiliated Hospital https://orcid.org/0000-0002-0894-2444

\section{Research}

Keywords: Coronavirus Disease 2019, Anxiety, Depression, Sleep Quality, Influencing Factors

Posted Date: May 22nd, 2020

DOI: https://doi.org/10.21203/rs.3.rs-30347/v1

License: (우 (i) This work is licensed under a Creative Commons Attribution 4.0 International License. Read Full License 


\section{Abstract \\ Background}

The COVID-19 pandemic is a major health crisis has led to adverse mental health consequences in the general public, medical staff, and individual in self isolation. In order to stop transmission of the virus and save lives, Fangcang shelter hospitals were developed and used for the first time in China. However, there is no research on mental health problems in Fangcang shelter hospitals patients during the COVID-19 outbreak. The aim of this study was to survey the prevalence and major influencing factors of anxiety, depression among the hospitalized Coronavirus Disease 2019 (COVID-19) cases in Fangcang shelter hospital.

\section{Methods}

From February 23rd, 2020, to February 26th, 2020, we obtained the information of demographic data, clinical symptoms, and assessed the mental health status, sleep quality by using an online questionnaire including self-rating anxiety scale (SAS), self-rating depressive scale (SDS) and pittsburgh sleep quality index (PSQI) at Jianghan Fangcang shelter hospital. We assessed the prevalence of anxiety, depression symptoms and poor sleep quality via the scores of SAS, SDS and PSQI. We explored the influencing factors of anxiety and depression in COVID-19 patients using multivariable logistic regression models.

\section{Results}

We collected data from 307 COVID-19 patients in Jianghan Fangcang shelter hospital. The prevalence of anxiety, depression symptoms were $18.6 \%$ and $13.4 \%$, respectively. Poor Sleep quality, number of current physical symptoms $\geq 2$ were independent risk factors for anxiety symptoms $(P<0.05)$; female, family member confirmed COVID-19, number of current physical symptoms $\geq 2$ were independent risk factors for depression symptoms $(P<0.05)$. PSQI scores were significant positively associate with SAS scores and SDS scores $(P \otimes 0.05)$.

\section{Conclusions}

Anxiety and depression are common among the COVID-19 patients in Fangcang shelter hospital. Those with more current physical symptoms, poor sleep quality are more likely to have anxiety. Females, those with their family members diagnosed with COVID-19, more current physical symptoms are more vulnerable to depression symptom. Our findings can be used to formulate targeted psychological interventions to reduce adverse psychological impacts in Fangcang shelter hospital during the outbreak of epidemic disease in the future. 
Originating as a cluster of unexplained cases of pneumonia, Coronavirus Disease 2019(COVID-19), was first identified in Wuhan, Hubei Province, China since December 2019[1]. As the virus spreads increasingly worldwide, the Coronavirus Disease 2019(COVID-19) pandemic is a global health threat and has the most devastating consequences with an actual or potential impact on citizens of all nations [2].

In addition to physical damage for patients, Widespread outbreaks of infectious disease, such as Ebola virus disease (EVD) and severe acute respiratory syndrome (SARS), was also associated with psychological distress and symptoms of mental illness $[3,4]$. Results from prospective studies consistently indicate psychological distress as a predictor for future health and disease outcomes [5]. As other infectious diseases, Preliminary evidence suggests that COVID-19 has also caused public panic and mental health stress; symptoms of anxiety and depression are common psychological reactions to the COVID-19 pandemic, and may be associated with socio-demographic, sleep quality [6-9]. However, previous studies focused mainly on the mental health of the COVID-19 epidemic among the general population, medical staff, and individuals in self isolation [10]. we know very little about the psychological effects of patients with COVID-19.[11]

To control the source of infection and save lives, China adopted strategies and tactics including establishment of Fangcang shelter hospitals in Hubei Province [12]. Fangcang shelter hospital is a novel public health concept which was developed and used for the first time in China to tackle the coronavirus disease2019 (COVID-19) outbreak [13]. The Fangcang shelter hospitals are large, temporary hospitals built by converting public venues, such as stadiums and exhibition centers, into health-care facilities to receive non-seriously ill individuals with positive SARS-CoV-2 RT-PCR tests from their families and communities, while providing disease monitoring, medical care, food, shelter, and social activities [13, 14]. To relieve the huge pressure on the health-care system, Fangcang shelter hospitals have also been crucial to the quick containment of COVID-19 in China, and provide an encouraging example for other countries [15]. As the COVID-19 pandemic spreads globally, Fangcang Shelter hospitals as part of the COVID-19 response in other countries not only China [13].

Based on the above research evidence on the public and medical staff, we speculate that the mental health of the Fangcang shelter hospitals patients may also be affected during the COVID-19 outbreak. Now, there is no research on mental health problems in Fangcang shelter hospitals patients during the COVID-19 outbreak in China. Well understanding of the psychosocial problems about Fangcang shelter hospitals patients, can provide important guidance to carry out timely psychological interventions for targeted populations in need and manage well Fangcang shelter hospital during the outbreak of epidemic disease in the future. For this purpose, the prevalence of anxiety and depression symptoms, and potential influencing factors contributing to anxiety, depression were detected.

\section{Methods}

\section{Design, setting, Participants}


This was a cross-sectional study performed via an anonymous online questionnaire from February 23rd to February 26th, 2020 in Jianghan Fangcang shelter hospital, wuhan, China. The designer and operator were doctors who worked in Jianghan Fangcang shelter hospital. We aimed to survey the prevalence and major influencing factors of anxiety, depression among the hospitalized Coronavirus Disease 2019 (COVID-19) cases in Fangcang shelter hospital. All participants met inclusion criteria of COVID-19 diagnosis according to the guidance from National Health Commission of the People's Republic of China (NHCPRC) [16], and all study respondents volunteered to participate in the study and signed informed consent online. Exclusion criteria included previously diagnosed severe psychiatric illnesses (e.g. schizophrenia, bipolar disorder, anxiety disorder, depression disorder), inability to complete or failure to fully complete an online questionnaire, oral drugs can cause side effects associated with anxiety, depression, insomnia.

\section{Measures}

The Participants scanned the QR codes through their mobile phones and completed questionnaires. The study questionnaire, comprised five main components including demographic characteristics, clinical characteristics, Self-Rating Anxiety Scale (SAS), self-rating depression scale (SDS), pittsburgh sleep quality index (PSQI).

Among them, we collected the current physical symptoms and comorbidities which were designed on the basis of Previous literature [17]. Participants had to indicate if they were currently experiencing any of the 14 listed physical symptoms(fever, cough, sputum production, shortness of breath,chest pain, fatigue, sore or discomfort throat, nasal congestion, conjunctival congestion, hemoptysis, headache, diarrhea, abdominal pain, myalgia or arthralgia). Comorbidities (chronic bronchitis or chronic obstructive pulmonary disease, asthma, hypertension, diabetes, coronary heart disease, cerebrovascular disease, connective tissue diseases, chronic renal disease, cancer) were also collected.

Anxiety and depression symptoms were assessed via the SAS and SDS questionnaire. The SAS and SDS questionnaire both contained 20 items consisting of four grades, with questions based on feelings of mood in the previous seven days. An aggregate score of 20 was then multiplied by 1.25 , with higher scores indicating more severe levels of anxiety and depression [18]. Cut-off scores of $\geq 50$ in SAS and $\geq 53$ in SDS represent a positive screen of depression, anxiety symptoms [18].

Sleep quality was assessed via the PSQI questionnaire. PQSI questionnaire contains seven items that included sleep quality, sleep duration, sleep latency, habitual sleep efficiency, sleep disturbance, use of sleeping medications, and daytime dysfunction [19]. Each dimension scored between $0-3$, with a total score ranging from $0-21$, and a higher score imply lower sleep quality. Poor sleep quality was defined as a total score of $\geq 6$ [20].

\section{Statistical analysis}

All statistical analyses were performed using IBM SPSS AMOS version 25. Continuous data coincided with normal distribution were presented as mean \pm standard deviation $(M \pm S D)$, while those of non-normal distribution were described as M (Q1, Q3); t-tests were used for comparing the normal distributional 
questionnaire and SAS, SDS scores. Univariate analyses of anxiety and depression symptoms were performed using the chi-squared $\left(\chi^{2}\right)$ tests; Any covariates that achieved $P<0.10$ for the bivariate analyses in the univariate analyses as inclusion criterion, the multivariable logistic regression models were built with forward LR variable selection method to identify independent factors associated with anxiety and depression, A $P$-value $<0.05$ was considered statistically significant.

\section{Results}

\section{General characteristics and prevalence of anxiety and depression}

A total of 307 patients participated in our study, among them, 57 (18.6\%) had anxiety and 41 (13.4\%), 260 $(84.7 \%)$ had PSQI-defined poor sleep quality; the top three coexisting illness were hypertension $(16.0 \%)$, chronic bronchitis or chronic obstructive pulmonary disease(13.0\%), diabetes(4.6\%), please refer to Fig. 1; Currently asymptomatic patients were 20; the top three Currently physical symptoms were cough $(26.4 \%)$, shortness of breath (24.4\%), sore or discomfort throat(17.9\%), please refer to Fig. 2.

The data of demographic, clinical characteristics and the differences in incidence of anxiety and depression symptoms among different groups are shown in Table 1 . Based on $P<0.10$ as screening covariates, family member confirmed COVID-19 $\left(\chi^{2}=3.334, P=0.068\right)$, number of current physical symptoms $\left(\chi^{2}=18.760, P<\right.$ $0.001)$, symptoms change after hospitalization $\left(\chi^{2}=5.952, P=0.051\right)$, poor sleep quality $\left(\chi^{2}=5.449, P=\right.$ 0.020 )were related factors of anxiety symptom, please refer to Table $1 ; \operatorname{Gender}\left(\chi^{2}=17.169, P<0.001\right)$, education level $\left(\chi^{2}=5.264, P=0.072\right)$, smoking history $\left(\chi^{2}=4.039, P=0.044\right)$, drinking history $\left(\chi^{2}=3.024 P=\right.$ 0.082), family member confirmed COVID-19 $\left(\chi^{2}=4.707, P=0.030\right)$, number of current physical symptoms $\left(\chi^{2}\right.$ $=14.812, P<0.001)$, Symptoms change after hospitalization $\left(\chi^{2}=4.696 P=0.096\right)$, Poor sleep quality $\left(\chi^{2}=\right.$ 4.696, $P=0.046$ ) were the related factors of depression symptom, please refer to Table 1. 
Table 1

General characteristics of the sample

\begin{tabular}{|c|c|c|c|c|c|c|c|c|}
\hline Characteristics & Anxiety & $\begin{array}{l}\text { No } \\
\text { anxiety }\end{array}$ & $x^{2}$ & $p$ & Depression & $\begin{array}{l}\text { No } \\
\text { depression }\end{array}$ & $x^{2}$ & $p$ \\
\hline Gender & & & 1.627 & 0.202 & & & 17.169 & $\iota_{0.001}^{<}$ \\
\hline Male & 28 & 146 & & & 11 & 163 & & \\
\hline Feale & 29 & 104 & & & 30 & 103 & & \\
\hline Age(year) & & & & & & & 0.799 & 0.671 \\
\hline$\leq 44$ & 28 & 128 & & & 20 & 136 & & \\
\hline $45 \llbracket 59$ & 25 & 94 & 1.288 & 0.525 & 18 & 101 & & \\
\hline$\geq 60$ & 4 & 28 & & & 3 & 29 & & \\
\hline Marital status & & & 2.762 & 0.251 & & & 3.002 & 0.238 \\
\hline Single & 5 & 32 & & & 5 & 32 & & \\
\hline Married & 46 & 205 & & & 31 & 220 & & \\
\hline $\begin{array}{l}\text { Divorced or } \\
\text { widowed }\end{array}$ & 6 & 13 & & & 5 & 14 & & \\
\hline $\begin{array}{l}\text { Education } \\
\text { level }\end{array}$ & & & 0.074 & 0.964 & & & 5.264 & 0.072 \\
\hline $\begin{array}{l}\text { Middle school } \\
\text { or below }\end{array}$ & 14 & 58 & & & 13 & 59 & & \\
\hline High school & 14 & 65 & & & 14 & 65 & & \\
\hline $\begin{array}{l}\text { College or } \\
\text { above }\end{array}$ & 29 & 127 & & & 14 & 142 & & \\
\hline BMI $(\mathrm{kg} / \mathrm{m} 2)$ & & & 0.274 & 0.872 & & & 0.869 & 0.647 \\
\hline$\llbracket 24$ & 25 & 119 & & & 22 & 122 & & \\
\hline $24 \llbracket 28$ & 24 & 97 & & & 14 & 107 & & \\
\hline$\llbracket 28$ & 8 & 34 & & & 5 & 37 & & \\
\hline Comorbidity & & & 0.993 & 0.319 & & & 0.021 & 0.885 \\
\hline Yes & 29 & 109 & & & 18 & 120 & & \\
\hline No & 28 & 141 & & & 23 & 146 & & \\
\hline $\begin{array}{l}\text { Smoking } \\
\text { history }\end{array}$ & & & 0.752 & 0.386 & & & 4.039 & 0.044 \\
\hline
\end{tabular}

Loading [MathJax]/jax/output/CommonHTML/fonts/TeX/fontdata.js iriables. 


\begin{tabular}{|c|c|c|c|c|c|c|c|c|}
\hline Characteristics & Anxiety & $\begin{array}{l}\text { No } \\
\text { anxiety }\end{array}$ & $x^{2}$ & $p$ & Depression & $\begin{array}{l}\text { No } \\
\text { depression }\end{array}$ & $x^{2}$ & $p$ \\
\hline Yes & 10 & 57 & & & 4 & 63 & & \\
\hline No & 47 & 193 & & & 37 & 203 & & \\
\hline $\begin{array}{l}\text { Drinking } \\
\text { history }\end{array}$ & & & 1.099 & 0.294 & & & 3.024 & 0.082 \\
\hline Yes & 10 & 60 & & & 5 & 65 & & \\
\hline No & 47 & 190 & & & 36 & 201 & & \\
\hline Inpatient days & & & 0.070 & 0.966 & & & 1.424 & 0.491 \\
\hline$\leq 7$ & 7 & 34 & & & 5 & 36 & & \\
\hline $8 \rrbracket 14$ & 9 & 39 & & & 4 & 44 & & \\
\hline Q14 & 41 & 177 & & & 32 & 186 & & \\
\hline $\begin{array}{l}\text { Family } \\
\text { member } \\
\text { confirmed } \\
\text { COVID-19 }\end{array}$ & & & 3.334 & 0.068 & & & 4.707 & 0.030 \\
\hline Yes & 32 & 107 & & & 25 & 114 & & \\
\hline No & 25 & 143 & & & 16 & 152 & & \\
\hline $\begin{array}{l}\text { Current nucleic } \\
\text { acid result }\end{array}$ & & & 2.010 & 0.156 & & & 0.747 & 0.388 \\
\hline Negative & 36 & 132 & & & 25 & 143 & & \\
\hline Positive & 21 & 118 & & & 16 & 123 & & \\
\hline $\begin{array}{l}\text { Number of } \\
\text { current } \\
\text { physical } \\
\text { symptoms }\end{array}$ & & & 18.760 & $\begin{array}{l}<.001 \\
0.00\end{array}$ & & & 14.812 & $\begin{array}{l}< \\
0.001\end{array}$ \\
\hline$\leq 1$ & 22 & 173 & & & 15 & 180 & & \\
\hline$\geq 2$ & 35 & 77 & & & 26 & 86 & & \\
\hline $\begin{array}{l}\text { Symptoms } \\
\text { change after } \\
\text { hospitalization }\end{array}$ & & & 5.952 & 0.051 & & & 4.696 & 0.096 \\
\hline Better & 46 & 191 & & & 35 & 202 & & \\
\hline Worse & 5 & 8 & & & 3 & 10 & & \\
\hline Unchanged & 6 & 51 & & & 3 & 54 & & \\
\hline
\end{tabular}

Loading [MathJax]/jax/output/CommonHTML/fonts/TeX/fontdata.js iriables. 


\begin{tabular}{|c|c|c|c|c|c|c|c|c|}
\hline Characteristics & Anxiety & $\begin{array}{l}\text { No } \\
\text { anxiety }\end{array}$ & $x^{2}$ & $p$ & Depression & $\begin{array}{l}\text { No } \\
\text { depression }\end{array}$ & $x^{2}$ & $p$ \\
\hline $\begin{array}{l}\text { Poor sleep } \\
\text { quality }\end{array}$ & & & 5.449 & 0.020 & & & 3.971 & 0.046 \\
\hline Yes & 54 & 206 & & & 39 & 221 & & \\
\hline No & 3 & 44 & & & 2 & 45 & & \\
\hline
\end{tabular}

\section{Risk factors for anxiety and depression}

The multivariate logistic regression analyses to predict risk factors of anxiety and depression are presented in Table 2. Poor Sleep quality (odds ratio [OR], 3.655, 95\% confidence interval [Cl], $1.074 \sim 12.433 ; P=0.038$ ), number of current physical symptoms $\geq 2(\mathrm{OR}, 3.504 ; 95 \% \mathrm{Cl}, 1.919 \sim 6.398 ; P<0.01)$ were independent risk factors for anxiety symptoms, Omnibus test of model coefficients showed that model was significant, $\left(\chi^{2}=\right.$ 23.905, $P \otimes 0.001)$, the goodness of fit of model with Hosmer and Lemeshow test showed was perfect $\left(\chi^{2}=\right.$ $0.118 \triangle P=0.943)$, please refer to Table 2; female (OR, 5.878; 95\% Cl, $2.657 \sim 13.005 ; P<0.001)$, family member confirmed COVID-19(OR, 2.81; $95 \% \mathrm{Cl}, 1.337 \sim 5.911 ; P=0.006)$, number of current physical symptoms $\geq 2(\mathrm{OR}, 4.145 ; 95 \% \mathrm{Cl}, 1.994 \sim 8.616 ; P<0.001)$ were independent risk factors for depression symptoms, Omnibus test of model coefficients showed that model was significant, $\left(\chi^{2}=40.508 \rrbracket P \square 0.001\right)$, the goodness of fit of model with Hosmer and Lemeshow test showed was perfect $\left(\chi^{2}=4.344 \bigotimes P \otimes 0.630\right)$, please refer to Table 2 .

Table 2

Multivariate logistic regression analysis of factors influencing anxiety and depression

\begin{tabular}{|c|c|c|c|c|c|}
\hline variables & $B$ & $s_{\mathrm{X}}^{-}$ & Walds & $P$ & OR $(95 \% C l)$ \\
\hline \multicolumn{6}{|l|}{ Models for anxiety } \\
\hline Poor Sleep quality (yes vs no) & 1.296 & 0.625 & 4.304 & 0.038 & $\begin{array}{l}3.655(1.074 \sim \\
12.433)\end{array}$ \\
\hline $\begin{array}{l}\text { Number of current physical symptoms }(\geq 2 \\
\text { VS } \leq 1)\end{array}$ & 1.254 & 0.307 & 16.657 & $<001$ & $3.504(1.919 \llbracket 6.398)$ \\
\hline \multicolumn{6}{|l|}{ Models for depression } \\
\hline Gender (female vs male) & 1.771 & 0.405 & 19.111 & $<.001$ & $\begin{array}{l}5.878(2.657 \sim \\
13.005)\end{array}$ \\
\hline $\begin{array}{l}\text { Family member confirmed COVID-19(yes vs } \\
\text { no) }\end{array}$ & 1.034 & 0.379 & 7.431 & 0.006 & $\begin{array}{l}2.811(1.337 \sim \\
5.911)\end{array}$ \\
\hline $\begin{array}{l}\text { Number of current physical symptoms ( } \geq 2 \\
\text { VS } \leq 1 \text { ) }\end{array}$ & 1.422 & 0.373 & 14.506 & $<.001$ & $\begin{array}{l}4.145(1.994 \sim \\
8.616)\end{array}$ \\
\hline
\end{tabular}

$\mathrm{B}$, Partial regression weight; $\mathrm{OR}, s_{X}^{-}$, Standard of error, $\mathrm{OR}$, odds ratio; $\mathrm{Cl}$, confidence interval; Multivariate

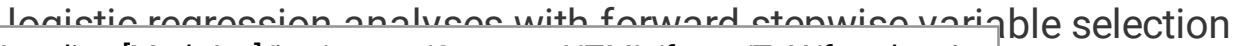
Loading [MathJax]/jax/output/CommonHTML/fonts/TeX/fontdata.js 


\section{Correlational analyses of scores between SAS, SDS and PSQI}

The scores of SAS and SDS of participants were (42.92 \pm 7.30$)$ and SDS (39.77 \pm 10.11$)$, scores of PSQI was $9(7,12)$. By using Spearman correlation tests, PSQI scores were significant positively associate with SAS scores $(r=0.177, P=0.002))$ and SDS scores $(r=0.327, P \otimes 0.001)$. Details are shown in Fig. 2.

\section{Discussion}

This cross-sectional study enrolled 307 participants firstly found the prevalence of anxiety, depression, poor sleep quality two months after the COVID-19 epidemic for Fangcang shelter hospital in China. Overall, $18.57 \%, 13.36 \%, 84.69 \%$ of the participants had symptoms of anxiety, depression, poor sleep quality, respectively. Compared with previous studies in the initial stage COVID-19 epidemic in China, which reported the occurrence of moderate to severe depressive, anxiety symptoms were $16.5 \%, 28.8 \%$ among the general population, respectively[8]; and symptoms of depression, anxiety were $50.4 \%, 44.6 \%$ among health care workers treating patients with COVID-19[21], this is in sharp contrast to a low prevalence of anxiety, depression in our study. Similarly, the same period study, conducted in China, which showed that prevalence rates of anxiety, depression of total participants (including medical health workers and nonmedical health workers) were $10.4 \%, 10.6 \%$ [22]. Hence, the prevalence rates difference in anxiety and depression might be caused by different research time. With the COVID-19 epidemic outbreak, the National Health Commission of China (NHC) has performed psychological crisis intervention into the general deployment of disease prevention and mental health professionals and expert groups Provide psychological intervention for different sub-populations, including patient isolation in Fangcang hospitals [13, 23]. Early psychological crisis intervention reduced the prevalence rates of negative psychological outcomes caused by the COVID19 outbreak. In addition, using the summary $t$ tests, both scores of SAS (42.92 \pm 7.30$)$ and SDS (39.77 \pm 10.11) in the participants of our study were higher than the scores in Chinese norms(SAS, $29.78 \pm 10.07, n=$ 1158;SDS, 33.46 $\pm 8.55, n=1340$ )[24] (both $P<0.05$ ), it indicates more severe levels of anxiety and depression in COVID-19 patients admitted to Fangcang hospital than general public. Clearly, anxiety and depression symptoms were common response to the COVID-19 outbreak, and patients in shelter Fangcang hospital had severe levels of anxiety, depression symptoms. The possible reason for these may be related to the uncertainty of the epidemic progression and feared that the disease was hard to recover [25].

After multivariate logistic regression analyses, our study further indicated the risk factors associated with anxiety and depression symptoms. Having poor sleep quality and presenting more current physical symptoms were risk factors for patient in shelter Fangcang hospital with anxiety symptoms. Sleep is an important time for the recuperation and rejuvenation of the brain. Unfortunately, a substantial body literature showed stressful life events and outbreaks of infectious disease including COVID-19 can affect the sleep quality[21, 26-29], 84.69\% of the participants in our study with the poor sleep quality demonstrate it again. Using the correlation analysis, we also found levels of anxiety symptoms are associate with sleep quality in COVID-19 patients admitted to shelter Fangcang hospital. Syntheses of longitudinal studies suggested sleep quality were bidirectionally related to anxiety [30]. There were large data investigating the effect of sleep quality on the anxiety symptom in other populations such as shift-workers, firefighters, paramedics,

Loading [MathJax]/jax/output/CommonHTML/fonts/TeX/fontdata.js ler odds of anxiety symptoms, greater anxiety were 
associate with poorer sleep quality [31-35]. Similarly, anxiety affects sleep quality because anxious people find it hard to fall asleep and wake up frequently [30]. In addition, we found patients with more symptoms were more vulnerable to anxiety symptoms. The possible reasons are as follows: firstly, common symptom of COVID-19 such as fever, short of breath, headache can induce anxiety symptom [36]; secondly, patients with more symptoms are more serious than asymptomatic patients, and the prevalence of anxiety is also related to the severity of the disease [37, 38]; lastly, patient with more symptoms were more worried about the progression of illness.

Another finding from the present study was female, family member confirmed COVID-19, more current physical symptoms were more likely to have anxiety symptom. As early as 1970s, Myrna Weissman underscored the gender difference in depression, and noted that women more easily experience depression than men [39], since then, there was a proliferation of research and theories on gender differences in depression. A recent meta-analysis after analyzing these researches showed that females are more vulnerable to not only depression disorders but also depression symptoms [40]. There now is consensus that the gender difference in depression has a multifactorial etiology, for example, there is a confluence of hormonal and neurodevelopmental changes that vary by sex during the pubertal transition and may influence the gender difference in depression [40]. In addition, when patient's family members were also diagnosed COVID-19, patients were more vulnerable to depression symptoms, owing to greater family burden and psychological distress[41, 42].Compared to patients with less physical symptoms, patients with more physical symptoms were more likely have depression symptoms, because they were more severe and prevalence of depression symptom in relation to the severity of the disease [38].

We also found that poor sleep quality was not independent risk factor for depression symptom, but the scores of PSQI was positively associate with SDS. Is there a contradiction? -but perhaps not. We consider because of weak correlation, so there was a difference in poor sleep quality between depression group and no depression group from the univariate analysis.

This study has limitations. Firstly, this is a cross-sectional design, the time frame is short and future longitudinal approach studies are need for follow up and intervention, secondly, psychological assessment was based on an online survey and on self-report tools. The use of clinical interviews is encouraged in future studies to draw a more comprehensive assessment of the problem. Thirdly, it is not a multinational, multicenter study, lack of data support from other Fangcang shelter hospitals.

\section{Conclusions}

In conclusion, our results identify the prevalence rates and risk factors of anxiety, depression symptoms among patients in the Fangcang shelter hospital. Anxiety and depression are common among the COVID-19 patients in Fangcang shelter hospital. Those with more physical symptoms,poor sleep quality are more vulnerable to anxiety symptom. Females and those with their family members diagnosed with COVID-19, more current physical symptoms are more vulnerable to depression symptom. The poorer the sleep quality is, the more serious symptoms of anxiety and depression there will be. Our findings can be used to 
formulate psychological interventions to reduce adverse psychological impacts in Fangcang shelter hospital during the outbreak of epidemic disease in the future.

\section{Declarations}

\section{Ethics approval and consent to participate}

This study was approved by the ethics committees of the First Affiliated Hospital of Zhengzhou University(no.2020-KY-169) All participants provided their online informed consent.

\section{Consent for publication}

Consent for publication is not applicable.

\section{Availability of data and materials}

The datasets used and/or analysed during the current study are available from the corresponding author on reasonable request.

\section{Competing interests}

The authors declare that they do not have a conflict of interest.

\section{Funding}

This work was supported by the National Natural Science Foundation of China (Grant No. U1904142).

\section{Authors' contributions}

Ling-Ling DAl, Xi WANG, Tian-Chi JIANG and Peng-Fei LI, designed this study. Ling-Ling DAl and Zhe CHENG collected the data. Yu Wang, Shujun WU searched the literature. Liu-Qun Jia, Meng Liu, and Lin An analyzed the data.

\section{Acknowledgements}

We thank all participants in this study.

\section{References}


1. Nishiura H, Jung SM, Linton NM, Kinoshita R, Yang Y, Hayashi K et al. The Extent of Transmission of Novel Coronavirus in Wuhan, China, 2020. J Clin Med. 2020;9(2). https://doi.org/10.3390/jcm9020330.

2. Rajkumar RP. Ayurveda and COVID-19: where psychoneuroimmunology and the meaning response meet. Brain Behav Immun. 2020. https://doi.org/10.1016/j.bbi.2020.04.056.

3. James PB, Wardle J, Steel A, Adams J. Post-Ebola psychosocial experiences and coping mechanisms among Ebola survivors: a systematic review. Trop Med Int Health. 2019;24(6):671-91. https://doi.org/10.1111/tmi.13226.

4. Gardner PJ, Moallef P. Psychological impact on SARS survivors: Critical review of the English language literature. Canadian Psychology/Psychologie canadienne. 2015;56(1):123-35.

5. Turner Al, Smyth N, Hall SJ, Torres SJ, Hussein M, Jayasinghe SU et al. Psychological stress reactivity and future health and disease outcomes: A systematic review of prospective evidence. Psychoneuroendocrinology. 2020;114:104599. https://doi.org/10.1016/j.psyneuen.2020.104599.

6. Bao Y, Sun Y, Meng S, Shi J, Lu L. 2019-nCoV epidemic: address mental health care to empower society. Lancet. 2020;395(10224):e37-e8. https://doi.org/10.1016/s0140-6736(20)30309-3.

7. Zhou SJ, Zhang LG, Wang LL, Guo ZC, Wang JQ, Chen JC et al. Prevalence and socio-demographic correlates of psychological health problems in Chinese adolescents during the outbreak of COVID-19. Eur Child Adolesc Psychiatry. 2020. https://doi.org/10.1007/s00787-020-01541-4.

8. Wang C, Pan R, Wan X, Tan Y, Xu L, Ho CS et al. Immediate Psychological Responses and Associated Factors during the Initial Stage of the 2019 Coronavirus Disease (COVID-19) Epidemic among the General Population in China. Int J Environ Res Public Health. 2020;17(5). https://doi.org/10.3390/ijerph17051729.

9. Huang Y, Zhao N. Chinese mental health burden during the COVID-19 pandemic. Asian J Psychiatr. 2020;51:102052. https://doi.org/10.1016/j.ajp.2020.102052.

10. Rajkumar RP. COVID-19 and mental health: A review of the existing literature. Asian J Psychiatr. 2020;52:102066. https://doi.org/10.1016/j.ajp.2020.102066.

11. Yuan R, Xu QH, Xia CC, Lou CY, Xie Z, Ge QM et al. Psychological status of parents of hospitalized children during the COVID-19 epidemic in China. Psychiatry Res. 2020;288:112953. https://doi.org/10.1016/j.psychres.2020.112953.

12. Peng F, Tu L, Yang Y, Hu P, Wang R, Hu Q et al. Management and Treatment of COVID-19: The Chinese Experience. Canadian Journal of Cardiology. 2020. https://doi.org/10.1016/j.cjca.2020.04.010.

13. Chen S, Zhang Z, Yang J, Wang J, Zhai X, Bärnighausen T et al. Fangcang shelter hospitals: a novel concept for responding to public health emergencies. Lancet. 2020. https://doi.org/10.1016/s01406736(20)30744-3.

14. Wang X, Fang J, Zhu Y, Chen L, Ding F, Zhou R et al. Clinical characteristics of non-critically ill patients with novel coronavirus infection (COVID-19) in a Fangcang Hospital. Clin Microbiol Infect. 2020. s://doi.org/10.1016/j.cmi.2020.03.032.

15. Prem K, Liu Y, Russell TW, Kucharski AJ, Eggo RM, Davies N et al. The effect of control strategies to reduce social mixing on outcomes of the COVID-19 epidemic in Wuhan, China: a modelling study.

Loading [MathJax]/jax/output/CommonHTML/fonts/TeX/fontdata.js s2468-2667(20)30073-6.

Page 12/16 
16. National Health Commission of the People's Republic of China. Diagnostic and treatment protocol for Novel Coronavirus Pneumonia (Trial version 6).(in chinese). 19 Feb 2020. http://www.nhc.gov.cn/yzygj/s7653p/202002/8334a8326dd94d329df351d7da8aefc2.shtml. Accessed 20 Feb 2020. 2020.

17. Guan WJ, Ni ZY, Hu Y, Liang WH, Ou CQ, He JX et al. Clinical Characteristics of Coronavirus Disease 2019 in China. N Engl J Med. 2020. https://doi.org/10.1056/NEJMoa2002032.

18. Li L WB, Gao TH, Tian J. Assessment of psychological status of inpatients with head and neck cancer before surgery. Zhonghua Er Bi Yan Hou Tou Jing Wai Ke Za Zhi. 2018;53(1):21-6.

19. Soldatos CR, Paparrigopoulos TJ. Sleep physiology and pathology: Pertinence to psychiatry. International Review of Psychiatry. 2005;17(4):213-28. https://doi.org/10.1080/09540260500104565.

20. Chen HC, Hsu NW, Chou P. Subgrouping Poor Sleep Quality in Community-Dwelling Older Adults with Latent Class Analysis - The Yilan Study, Taiwan. Sci Rep. 2020;10(1):5432. https://doi.org/10.1038/s41598-020-62374-4.

21. Lai J, Ma S, Wang Y, Cai Z, Hu J, Wei N et al. Factors Associated With Mental Health Outcomes Among Health Care Workers Exposed to Coronavirus Disease 2019. JAMA Netw Open. 2020;3(3): e203976. https://doi.org/10.1001/jamanetworkopen.2020.3976.

22. Zhang WR, Wang K, Yin L, Zhao WF, Xue Q, Peng M et al. Mental Health and Psychosocial Problems of Medical Health Workers during the COVID-19 Epidemic in China. Psychother Psychosom. 2020. https://doi.org/10.1159/000507639.

23. Li W, Yang Y, Liu ZH, Zhao YJ, Zhang Q, Zhang L et al. Progression of Mental Health Services during the COVID-19 Outbreak in China. Int J Biol Sci. 2020;16(10):1732-8. https://doi.org/10.7150/ijbs.45120.

24. Li L, Wang BQ, Gao TH, Tian J. [Assessment of psychological status of inpatients with head and neck cancer before surgery]. Zhonghua Er Bi Yan Hou Tou Jing Wai Ke Za Zhi. 2018;53(1):21-6. https://doi.org/10.3760/cma.j.issn.1673-0860.2018.01.005.

25. Huang Y, Zhao N. Generalized anxiety disorder, depressive symptoms and sleep quality during COVID19 outbreak in China: a web-based cross-sectional survey. Psychiatry Res. 2020;288:112954. https://doi.org/10.1016/j.psychres.2020.112954.

26. Li Y, Gu S, Wang Z, Li H, Xu X, Zhu H et al. Relationship Between Stressful Life Events and Sleep Quality: Rumination as a Mediator and Resilience as a Moderator. Front Psychiatry. 2019;10:348. https://doi.org/10.3389/fpsyt.2019.00348.

27. Lotsch F, Schnyder J, Goorhuis A, Grobusch MP. Neuropsychological long-term sequelae of Ebola virus disease survivors - A systematic review. Travel Med Infect Dis. 2017;18:18-23. https://doi.org/10.1016/j.tmaid.2017.05.001.

28. Chen R, Chou KR, Huang YJ, Wang TS, Liu SY, Ho LY. Effects of a SARS prevention programme in Taiwan on nursing staff's anxiety, depression and sleep quality: a longitudinal survey. Int J Nurs Stud. 2006;43(2):215-25. https://doi.org/10.1016/j.jinurstu.2005.03.006.

29. Chew NWS, Lee GKH, Tan BYQ, Jing M, Goh Y, Ngiam NJH et al. A multinational, multicentre study on the psychological outcomes and associated physical symptoms amongst healthcare workers during Loading [MathJax]/jax/output/CommonHTML/fonts/TeX/fontdata.js //doi.org/10.1016/j.bbi.2020.04.049. 
30. Alvaro PK, Roberts RM, Harris JK. A Systematic Review Assessing Bidirectionality between Sleep Disturbances, Anxiety, and Depression. Sleep. 2013;36(7):1059-68. https://doi.org/10.5665/sleep.2810.

31. Khan WAA, Conduit R, Kennedy GA, Jackson ML. The relationship between shift-work, sleep, and mental health among paramedics in Australia. Sleep Health. 2020. https://doi.org/10.1016/j.sleh.2019.12.002.

32. Sanchez SE, Friedman LE, Rondon MB, Drake CL, Williams MA, Gelaye B. Association of stress-related sleep disturbance with psychiatric symptoms among pregnant women. Sleep Med. 2020;70:27-32. https://doi.org/10.1016/j.sleep.2020.02.007.

33. Carey MG, Al-Zaiti SS, Dean GE, Sessanna L, Finnell DS. Sleep problems, depression, substance use, social bonding, and quality of life in professional firefighters. J Occup Environ Med. 2011;53(8):928-33. https://doi.org/10.1097/JOM.0b013e318225898f.

34. Brown JP, Martin D, Nagaria Z, Verceles AC, Jobe SL, Wickwire EM. Mental Health Consequences of Shift Work: An Updated Review. Curr Psychiatry Rep. 2020;22(2):7. https://doi.org/10.1007/s11920020-1131-z.

35. Gould CE, Spira AP, Liou-Johnson V, Cassidy-Eagle E, Kawai M, Mashal N et al. Association of Anxiety Symptom Clusters with Sleep Quality and Daytime Sleepiness. J Gerontol B Psychol. Series B, 2018;73(3):413-20. https://doi.org/10.1093/geronb/gbx020.

36. Fitzgerald PJ. Serious infection may systemically increase noradrenergic signaling and produce psychological effects. Med Hypotheses. 2020;139:109692. https://doi.org/10.1016/j.mehy.2020.109692.

37. da Silva AM, Vilhena E, Lopes A, Santos E, Gonçalves MA, Pinto C et al. Depression and anxiety in a Portuguese MS population: Associations with physical disability and severity of disease. Journal of the Neurological Sciences. 2011;306(1):66-70. https://doi.org/10.1016/j.jns.2011.03.042.

38. Piontek K, Ketels G, Albrecht R, Schnurr U, Dybowski C, Brunahl CA et al. Somatic and psychosocial determinants of symptom severity and quality of life in male and female patients with chronic pelvic pain syndrome. J Psychosom Res. 2019;120:1-7. https://doi.org/10.1016/j.jpsychores.2019.02.010.

39. Weissman MM, Klerman GL. Sex differences and the epidemiology of depression. Arch Gen Psychiatry. 1977;34(1):98-111. https://doi.org/10.1001/archpsyc.1977.01770130100011.

40. Salk RH, Hyde JS, Abramson LY. Gender differences in depression in representative national samples: Meta-analyses of diagnoses and symptoms. Psychol Bull. 2017;143(8):783-822. https://doi.org/10.1037/bul0000102.

41. Jo M, Song MK, Knafl GJ, Beeber L, Yoo YS, Van Riper M. Family-clinician communication in the ICU and its relationship to psychological distress of family members: A cross-sectional study. Int J Nurs Stud. 2019;95:34-9. https://doi.org/10.1016/j.ijnurstu.2019.03.020.

42. Van der Werf HM, Luttik MLA, Francke AL, Roodbol PF, Paans W. Students growing up with a chronically ill family member; a survey on experienced consequences, background characteristics, and risk factors. BMC Public Health. 2019;19(1):1486. https://doi.org/10.1186/s12889-019-7834-6.

\section{Figures}

Loading [MathJax]/jax/output/CommonHTML/fonts/TeX/fontdata.js

Page $14 / 16$ 
a)

proportion of symptoms(\%)
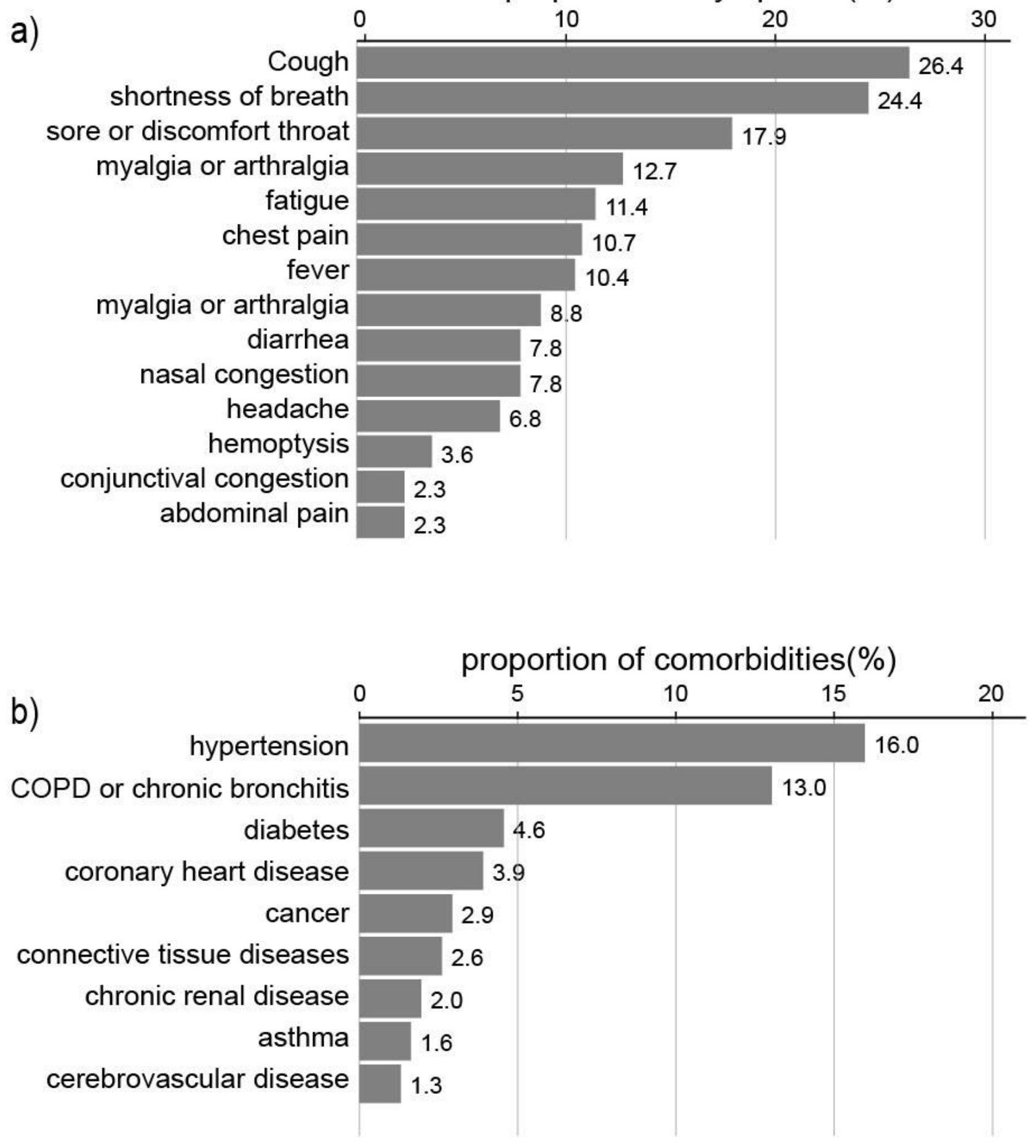

Figure 1

a: Histogram of the frequency distribution of Comorbidities. b: Histogram of the frequency distribution of current physical symptoms. COPD: chronic obstructive pulmonary disease. 

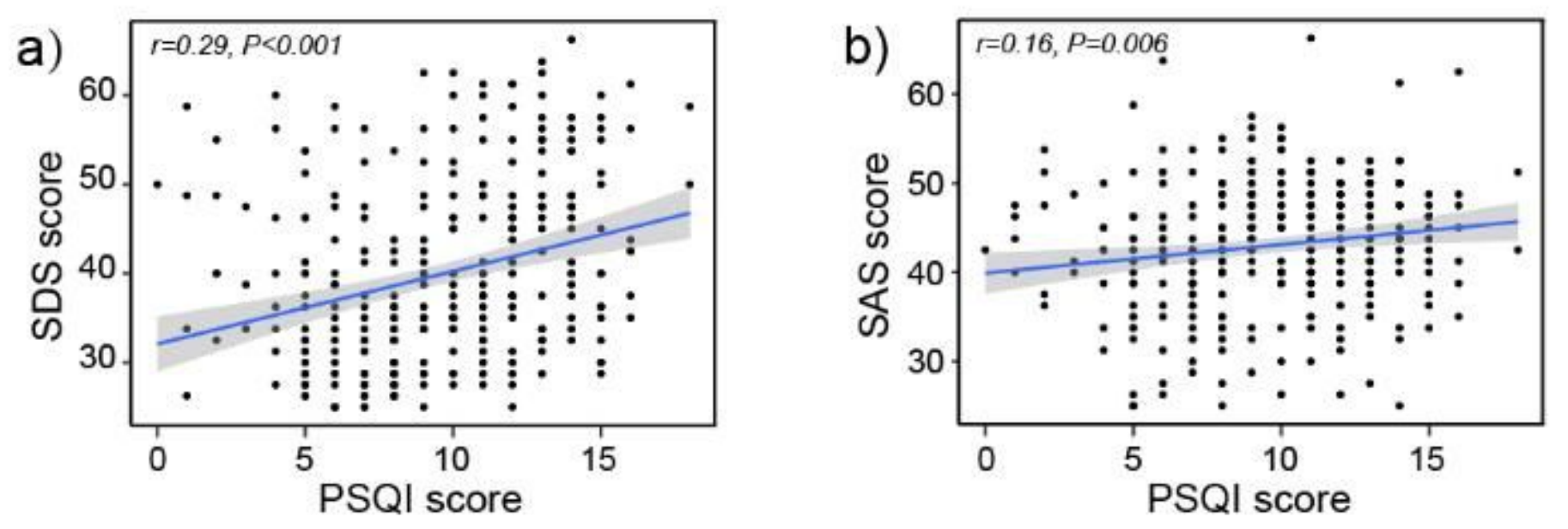

Figure 2

$\mathrm{a} \bowtie$ Spearman correlation between PSQI scores and SAS scores. b: Spearman correlation between PSQI scores and SDS scores. Oblique lines are fitting lines The grey areas indicate a $95 \%$ confidence interval of fitting lines. 